Matgorzata Pilecka

ORCID: 0000-0002-4815-2949

Ateneum - Szkoła Wyższa w Gdańsku

\title{
Fałszywe nuty w piosenkach dziecięcych. O oczywistych i mniej oczywistych funkcjach piosenek dla dzieci we wczesnej edukacji
}

\section{Wprowadzenie}

Współcześnie piosenkę dziecięcą stosuje się w różnych dziedzinach pedagogicznych: w edukacji przedszkolnej i wczesnoszkolnej, w pracy terapeutycznej, w nauczaniu języków obcych itp. Wybitna polska teoretyk i pedagog muzyki Elżbieta Frołowicz wymienia następujące edukacyjne zastosowania muzyki (w tym piosenek dla dzieci) i wywiedzionych z niej wszelkiego rodzaju działań artystycznych: 1) środek animujący, 2) środek relaksacji, 3) środek prowokowania i ćwiczenia różnego typu zachowań wartościujących (zarówno werbalnych, jak i niewerbalnych), 4) przedmiot poznania, przeżywania i wartościowania (Frołowicz 2011: 16). Nie ulega zatem wątpliwości, że potencjał edukacyjny piosenki dziecięcej jest ogromny. Włączanie jej w proces dydaktyczny wydaje się jednak obarczone pewnym ryzykiem, którego naturę pragnę zgłębić w tym artykule. Próby całościowego i interdyscyplinarnego ujmowania piosenek dziecięcych są na gruncie pedagogiki, jak dotąd, nieliczne. Być może wynika to z przeświadczenia, że stanowi ona immanentny element dzieciństwa i wczesnej edukacji, a ta jej „naturalna obecność” nie wzbudza żadnych kontrowersji. Moją ambicją jest wyodrębnienie piosenki dziecięcej spośród innych pozornie stałych i bezdyskusyjnych pojęć pedagogicznych, aby poddać ją konstruktywnej krytyce. 


\section{Piosenka dziecięca - cechy dystynktywne gatunku}

W literaturze pedagogicznej trudno znaleźć jednoznaczną definicję piosenki dziecięcej. Zwykle jej pojęcie autorzy traktują jako oczywiste, niewymagające skrupulatnych wyjaśnień. Definicje zastępuje się po prostu synonimicznymi określeniami piosenek dziecięcych, na przykład: piosenki dla dzieci, (wokalna) muzyka dziecięca, repertuar dziecięcy, zbiór piosenek dziecięcych itp. Próby dookreślenia tego pojęcia podjęli się badacze folkloru dziecięcego - Iona i Peter Opie. Tłumaczą jej istotę jako „przedszkolny wiersz podkładany pod muzykę, piosenkę ułożoną przez dzieci i funkcjonującą $\mathrm{w}$ grupie rówieśników lub nowoczesne utwory tworzone na potrzeby rozrywki, na użytek domowy lub edukacyjny" (I. Opie, P. Opie 1959: 21-22). Autorzy w tej charakterystyce zwracają uwagę, że piosenka dziecięca może wywodzić się z różnych źródeł (spontaniczna działalność dzieci, intencjonalna działalność osób dorosłych lub dziedzictwo kultury ludowej). Podkreślają również mnogość jej zastosowań w życiu (małego) człowieka, w tym jej funkcję rozrywkową i edukacyjną. Inni badacze, próbując wyodrębnić piosenkę dziecięcą spośród ogółu tekstów kultury, powołują się na kryterium wykonawstwa (możliwości technicznych dziecka i/lub faktycznego wykonywania utworu) oraz pożądanego odbiorcy piosenki. I tak, parafrazując nieco definicję przytoczoną przez Janusza Sławińskiego, można stwierdzić, że piosenka dziecięca jest utworem słowno-muzycznym, przeznaczonym do wykonywania przez dzieci lub zespół (chór) dziecięcy. Lub: utworem słowno-muzycznym, przeznaczonym do wykonywania przez śpiewaka-solistę lub zespół dla dziecięcej publiczności (zob. Sławiński 1988: 357). Ostatnia grupa definicji koncentruje się na dychotomii treści adekwatne vs nieadekwatne dla dzieci. Jej źródło tkwi w społecznych przekonaniach dotyczących dziecka i dzieciństwa, takich jak stereotyp „sielskiego i beztroskiego dzieciństwa” czy tabuizacja różnych sfer życia (np. seksualności człowieka, cierpienia, realnych problemów społecznych). W tym ujęciu definicja piosenki dziecięcej oznacza tylko tyle, że jej treść nie zawiera mogących budzić niepokój elementów, między innymi wulgaryzmów, opisów aktu seksualnego czy aktów przemocy.

Podsumowując rozważania na temat „dziecięcości” piosenki dziecięcej, chciałabym raz jeszcze podkreślić, że cecha ta może odnosić się do wieku autora utworu, do treści uważanych za właściwe (adekwatne) dla dzieci lub do specyficznej budowy utworu, uwzględniającej charakter języka i/lub potrzeby rozwojowe dziecka. W danym utworze słowno-muzycznym wszystkie te elementy mogą ze sobą współwystępować lub być jedynie zasygnalizowane. Z praktyki wynika jednak, że wśród piosenek dziecięcych wykorzystywanych faktycznie w przedszkolach i szkołach najczęściej spotykane są utwory wokalne tworzone przez dorosłych, o różnej - niestety - wrażliwości estetycznej i pedagogicznej. Warto podkreślić, że o tym, które piosenki faktycznie trafią (lub nie) do młodego odbiorcy, decydują osoby dorosłe pełniące funkcję pośredników. Jak z pewną goryczą pisze Ewa Szatan, „W zakresie kształtowania zainteresowań i gustów muzycznych [...] obserwujemy 
niepokojące zjawisko - bezkrytycznie, bezrefleksyjnie poddajemy się na co dzień wzorcom dostarczanym przez media, nie weryfikując i nie wartościując sztuki przede wszystkim dla najmłodszych" (Szatan 2007: 5). Od osób zawodowo zajmujących się edukacją najmłodszych można i należy zatem wymagać tego, aby przy wyborze utworów muzycznych do pracy pedagogicznej zwracały uwagę na ich wartość artystyczną, edukacyjną i wychowawczą.

\section{Oczywiste funkcje piosenki dziecięcej we wczesnej edukacji}

Piosenka dziecięca - od kołysanki począwszy - jest pierwszym spotkaniem dziecka ze światem muzyki. Będąc stosunkowo prostą formą muzyczną, stopniowo wprowadza najmłodszych w zjawisko różnic w wysokościach dźwięków, zmiany tempa, rytmu czy głośności melodii. Pod względem organizacyjnym piosenka jest też najbardziej dostępnym sposobem kontaktu z muzyką, ponieważ nie wymaga posiadania specjalistycznego sprzętu czy instrumentarium - poza głosem i sprawnym słuchem. Z tych względów piosenka dziecięca zyskała szczególne miejsce we współczesnych koncepcjach wychowania muzycznego.

Wychowanie muzyczne wpisuje się w ideę wychowania przez sztukę, zapoczątkowaną przez Herberta Reada w Education through Art (Wojnar 1965: 5), a rozpropagowaną w Polsce przez takich pedagogów jak Irena Wojnar, Stanisław Ossowski, Stefan Szuman czy Bogdan Suchodolski. Jak pisze Kazimierz Sośnicki (1967: 57), „początkowo motywem wprowadzenia wychowania estetycznego do wychowania szkolnego był motyw gospodarczy. Ale z czasem rozszerza się on na inne dziedziny życia ludzkiego i dąży do ogarnięcia estetyzmem całego procesu myślenia”. We współczesnych koncepcjach wychowania estetycznego wskazuje się na dwutorowość oddziaływań w zakresie kontaktu dziecka ze sztuką - na wychowanie przez sztukę i do odbioru sztuki. Pierwszy typ oddziaływań pedagogicznych ma na celu wykorzystanie sytuacji kontaktu ze sztuką do wszechstronnego rozwoju dziecka, w tym do kształtowania wrażliwości i wyobraźni poprzez styczność z wytworem kultury (utworem muzycznym, dziełem plastycznym, rzeźbą, instalacją artystyczną itp.). Jak mówił sławny polski rysownik komiksów Henryk Jerzy Chmielewski, autor przygód Tytusa, Romka i A’Tomka, kontakt ze sztuką ma nas „uczłowieczyć”. Natomiast program wychowania do odbioru sztuki powinien przekazywać dzieciom wiedzę i umiejętności niezbędne do świadomego korzystania z oferty kulturalnej, na przykład znajomość podstawowej terminologii, istotnych faktów historycznych, przedstawicieli różnych kierunków sztuki, znanych dzieł plastycznych i muzycznych. Suchodolski (1965: 22) stwierdza: „Mówiąc o wychowaniu estetycznym, możemy mieć na myśli nie tylko to, jak jednostka ludzka układa swój stosunek do dzieł sztuki, z którymi ma do czynienia, ale także i to, co dzieje się z jednostką ludzką pod wpływem dzieł sztuki i jak sztuka kształtuje całego człowieka”. Wychowanie estetyczne obejmuje różne obszary edukacji: plastyczną, techniczną, muzyczną, 
teatralną itp. Tutaj koncentruję się na tych zagadnieniach, które mają związek $\mathrm{z}$ piosenkami dziecięcymi, a więc głównie $\mathrm{z}$ wychowaniem muzycznym.

Wychowanie muzyczne, zwane również (wczesną) edukacją muzyczną, obejmuje zarówno wychowanie poprzez muzykę, jak i wychowanie do odbioru muzyki. Już Jan Ámos Komenský (1592-1670) w swym dziele Wielka dydaktyka zwracał uwagę na to, że śpiew jest umiejętnością powszechną, potrzebną do życia każdemu człowiekowi (Danielewicz 2013: 36). Dobroczynny wpływ kontaktu dziecka z muzyką od najmłodszych lat akcentowali różni przedstawiciele pajdocentryzmu. Jan Henryk Pestalozzi (1746-1827) twierdził, że o prawidłowym, harmonijnym rozwoju dziecka decyduje równowaga stymulacji intelektualnej, fizycznej i moralnej (Danielewicz 2013: 36). Źródło ekspresji artystycznej (w tym i muzycznej) lokalizował w sercu dziecka. Szczególną wartość prorozwojową Pestalozzi przypisywał śpiewaniu pieśni i piosenek, opracował także uproszczone metody nauczania śpiewu. Witold Danielewicz podkreśla: „Poglądy wyrażone w podręczniku Pestalozziego [...] dotyczące uproszczonych metod nauczania śpiewu, stały się krokami milowymi w rozwoju teoretycznych podstaw pedagogiki muzycznej" (Danielewicz 2013: 36). Szeroko zakrojony kontakt dziecka z muzyką zaplanowała również Maria Montessori (1870-1952) w swym programie pedagogicznym. Obejmował on między innymi: rozwijanie słuchu muzycznego, ćwiczenie pamięci i wyobraźni muzycznej, zapoznanie z notacją muzyczną, zapis nutowy ulubionych piosenek i melodii, podstawy kompozycji muzycznej i naukę gry na instrumentach (Danielewicz 2013: 37).

Charakteryzując współczesny model wczesnej edukacji muzycznej w polskiej szkole, Frołowicz wymienia trzy główne formy kontaktu ucznia z muzyką: , ,ekspresja wykonawcza (śpiew, ruch z muzyką, gra na instrumentach), ekspresja twórcza (improwizacja i twórczość muzyczna) oraz percepcja dzieła wsparta aktywnym słuchaniem muzyki" (Frołowicz 2011:25). Wszystkie te elementy - choć z różnym nasileniem - są obecne we współczesnych koncepcjach wychowania muzycznego. I warto zaznaczyć, że we wszystkich trzech wymienionych formach kontaktu ucznia z muzyką zastosowanie znajdują piosenki dla dzieci: jako materiał głosowy, podstawa do tworzenia akompaniamentu muzycznego i/lub ilustracji ruchowej. Współczesne modele wczesnej edukacji muzycznej w Polsce zostały opracowane na podstawie zachodnich trendów i innowacji w nauczaniu muzyki, a więc systemów autorstwa wybitnych pedagogów muzyki, między innymi: Emila Jaquesa-Dalcrozéa, Carla Orffa oraz Zoltána Kodály’a (Uchyła-Zroski 2013: 109). Proponowany przez nich repertuar wokalny jest bardzo zróżnicowany: obejmuje przyśpiewki, pieśni i piosenki ludowe, piosenki skomponowane specjalnie dla dzieci oraz piosenki towarzyszące zabawom muzycznym. Wspomniani twórcy chętnie wykorzystywali w swej pedagogicznej pracy muzyczne motywy folklorystyczne, a także odwoływali się do dorobku muzyki artystycznej. Na próżno szukać w ich działalności zajęć opartych na muzyce rozrywkowej czy kiczu muzycznym. Autorami wszystkich omówionych metod jednak byli profesjonalni muzycy, którzy w doborze repertuaru 
do pracy z dziećmi większą wagę przykładali do formy muzycznej utworu niż do jego warstwy słownej.

Współcześnie piosenka dziecięca jest stosowana w różnych dziedzinach „okołoedukacyjnych", takich jak: medycyna (na przykład muzykoterapia) (Danielewicz 2013: 30) czy logopedia (w szczególności terapia jąkania i logorytmika) (Walencik-Topiłko 2016). Dużym uznaniem cieszy się w Polsce Metoda Dobrego Startu (MDS) opracowana przez Martę Bogdanowicz na podstawie francuskiej koncepcji Le Bon Depart Thei Bugnet-van der Voort. Podstawą schematu zajęć MDS są specjalnie na ich potrzeby napisane piosenki dla dzieci, które stanowią tło dla innych aktywności: ćwiczeń usprawniających, zabaw ruchowych, ćwiczeń w pisaniu i rysowaniu. Marta Bogdanowicz, Małgorzata Barańska oraz Ewa Jakacka przygotowały pomoce dydaktyczne do realizowania założeń MDS, a wśród nich zestawy ćwiczeń dla dzieci pt.: „Od piosenki do literki” i „Piosenki do rysowania”. Nauczyciele edukacji wczesnoszkolnej i przedszkolnej, po ukończeniu certyfikowanego kursu, mogą wprowadzać elementy tej metody do swojego warsztatu pedagogicznego. Popularna w edukacji przedszkolnej stała się również metoda zabawowa opracowana i rozpropagowana przez Stowarzyszenie Klanza, a polegająca na prowadzeniu zabaw muzyczno-ruchowych przy użyciu chusty animacyjnej. Oprócz samej chusty nabyć można także zestaw płyt z muzyką specjalnie skomponowaną na potrzeby stosowania tej metody ${ }^{2}$. Artystyczną muzykę dla dzieci, w tym i piosenki dziecięce, propaguje także rodzinna firma POMELODY ${ }^{\circledR}$, udostępniając materiały muzyczne $\mathrm{w}$ formie cyfrowej, organizując warsztaty muzyczno-ruchowe i prowadząc sprzedaż płyt $\mathrm{z}$ autorską muzyką dziecięcą do użytku domowego i przedszkolnego/szkolnego ${ }^{3}$.

Warto podkreślić, że korzystanie z tych i innych alternatywnych metod nauczania muzyki najmłodszych uczniów ma charakter fakultatywny i tylko w niewielkim stopniu dotyczy szkolnictwa powszechnego w Polsce.

Nieoczywiste funkcje piosenki dziecięcej we wczesnej edukacji

Piosenka dziecięca kojarzy się w pierwszej kolejności ze wczesną edukacją, szczególnie z zajęciami przedszkolnymi: towarzyszy zabawom ruchowym (np. „Kółko graniaste”, „Chodzi lisek koło drogi”, „Mało nas do pieczenia chleba”), wspiera konstruowanie codziennej rutyny w placówce (np. piosenki na powitanie, piosenki na rozpoczęcie posiłków), stanowi element dziecięcych inscenizacji teatralnych, a także - w przekonaniu wielu nauczycieli - pomaga realizować program kształcenia. O ile pierwsze trzy wymienione funkcje (nazwałam je roboczo: funkcja

\footnotetext{
${ }^{1}$ Zob. strona domowa prof. zw. dr hab. Marty Bogdanowicz: https://ptd.edu.pl/proftest/mds.html [dostęp: 9.03.2020].

${ }^{2}$ Zob. strona internetowa Stowarzyszenia Klanza: http://klanza.org.pl/ [dostęp: 19.03.2020].

${ }^{3}$ Zob. strona internetowa POMELODY ${ }^{\oplus}$ : https://pomelody.com/ [dostęp: 19.03.2020].
} 
rekreacyjno-integracyjna, organizacyjna, artystyczna) raczej nie budzą kontrowersji, o tyle jej postulowana wartość merytoryczna skłania mnie do podjęcia głębszej refleksji.

Od słynnej (dla niektórych - osławionej) reformy edukacyjnej z 1999 roku wczesna edukacja, szczególnie w klasach I-III, przyjęła w Polsce formę tak zwaną zintegrowaną ${ }^{4}$. Określenie to od początku prowadziło do nieporozumień, ponieważ już na etapie przygotowań do wprowadzania zmian nie doprecyzowano, o jaki typ nauczania właściwie chodzi. Dorota Klus-Stańska i Marzenna Nowicka pochylają się nad problemem definiowania nauczania całościowego między innymi w książce Sensy i bezsensy edukacji wczesnoszkolnej. Autorki zwracają uwagę, że program kształcenia w klasach początkowych bazuje raczej na wolnych, głównie słownych skojarzeniach (asocjacjach) z danym tematem niż na dogłębnej, wieloaspektowej integracji wiedzy uczniów (Klus-Stańska, Nowicka 2005: 182-220).

Jak pisze Frołowicz, w „zakresie edukacji muzycznej w klasach młodszych konsekwencją tego [wprowadzenia zintegrowanego modelu nauczania - przyp. M.P.] stało się zepchnięcie muzyki na margines działalności szkolnej” (Frołowicz 2011: 9). Podobne obawy wyraża Beata Kamińska: „brak podziału na przedmioty w nauczaniu początkowym [...] może w konsekwencji doprowadzić do eksponowania jednego przedmiotu, który jest najbliższy danemu nauczycielowi, a marginalne potraktowanie pozostałych" (Kamińska 2013: 167). Natomiast Szatan, na podstawie swoich badań i obserwacji, jest zdania, że zaniedbania i zaniechania w obrębie wczesnej edukacji muzycznej od dawna są faktem, ponieważ „Nauczyciele często są świadomi swoich niepełnych kompetencji (np. spowodowanych brakiem wcześniejszych predyspozycji). Dlatego, w myśl lekarskiej zasady primum non nocere, wolą zaniechać działań aniżeli zaszkodzić" (Szatan 2006: 226). Jedyną aktywnością muzyczną niewykraczającą poza strefę nauczycielskiego komfortu zdaje się być piosenka dziecięca.

Piosenki dziecięce w tak pomyślanym - zintegrowanym - modelu nauczania zajęły bowiem „szczególne” miejsce. Przestały być traktowane jedynie jako podstawa edukacji muzycznej czy czynność integracyjno-organizacyjna. „Awansują” one w tym modelu do źródła wiarygodnej wiedzy o świecie, dobór repertuaru zaś zależy ściśle od tematu bloku zajęć lub konkretnej lekcji, na przykład: piosenki o zimie, piosenki o rodzinie, piosenki o przyrodzie itp. Historycy wychowania muzycznego wskazują, że cykle tematyczne realizowane obecnie we wczesnej edukacji mają swoje korzenie w socjalistycznym modelu kształcenia wypracowanym w latach pięćdziesiątych XX wieku. Jadwiga Uchyła-Zroski pisze:

Wszystkie środowiskowe imprezy artystyczne podporządkowane były wydarzeniom życia społecznego. Regulował je tzw. kalendarz roczny, na przykład święto plonów, Dzień Kobiet, Dzień Matki, Dzień Dziecka, okres adwentu, Bożego Narodzenia, karnawału, świąt wielkanocnych,

\footnotetext{
${ }^{4} \mathrm{~W}$ aktualnie obowiązującej podstawie programowej dla klas I-III czytamy: „W szkole podstawowej na I etapie edukacyjnym, obejmującym klasy I-III - edukacja wczesnoszkolna, edukacja realizowana jest w formie kształcenia zintegrowanego" (s. 15). Brakuje natomiast wyjaśnienia, jakiego typu działalność dydaktyczną należy rozumieć pod tym pojęciem.
} 
święta polityczne: 1 Maja, Dzień Wojska Polskiego, rocznica rewolucji październikowej. Najczęściej wydarzeniom tym towarzyszyły zebrania wiejskie, prelekcje i część rozrywkowa, jak: występy młodzieży szkolnej, festyny, zabawy ludowe na świeżym powietrzu, bufet (Uchyła-Zroski 2013: 102).

Chociaż nazwy niektórych świąt uległy zmianie, sama idea powtarzania uparcie tego samego schematu tematycznego po dziś dzień przetrwała w programach wczesnej edukacji. Rola piosenki dziecięcej w tym schemacie jest podrzędna, służebna wobec obowiązującego kalendarza tematycznego. Jerzy Dyląg pisze w tym kontekście o „nadmiernej eksploatacji piosenki dziecięcej” (Dyląg 2006: 235). W przywoływanych wcześniej profesjonalnych systemach kształcenia muzycznego (Jaques-Dalcroze’a, Orffa, Kodály’a) pieśń i piosenka stanowią podstawę rozwoju wokalnego, słuchowego i wykonawczego - jej treść jest zatem uzależniona od możliwości głosowych i emisyjnych dziecka, a dobór repertuaru obejmuje utwory o wysokich wartościach artystycznych. Obecnie jakość piosenki dziecięcej nie wydaje się aż tak ważna - istotne jest raczej to, czy najmłodsi śpiewają "na temat” lub „z okazji”. W opinii Małgorzaty Cackowskiej dzieci są wręcz „skazane na kicz” w zakresie oferty kulturalnej, z którą spotykają się w ramach instytucjonalnej edukacji (Cackowska 2015: 278). Warto zatem przywołać słowa Marii Przychodzińskiej-Kaciczak: „Skłonność do godzenia się pedagogów z repertuarem przeciętnym jest to zjawisko niedobre, bowiem muzyka na co dzień - piosenka, ma zasadniczy wpływ na formowanie się smaku muzycznego dzieci" (Przychodzińska-Kaciczak 1979: 200-201).

Teksty piosenek dziecięcych ukazują schematyczny, uproszczony obraz świata. Tymczasem ich obecność we wczesnej edukacji ma często charakter dosłowny, pomijający metaforyczny sens. Dobrym przykładem może być tutaj wpisanie piosenki Była sobie żabka mała w ściśle przyrodniczy temat „Mieszkańcy stawów i jezior”. Przeglądając pakiety edukacyjne przygotowane pod kątem realizacji podstawy programowej we wczesnej edukacji, znaleźć można więcej takich absurdów. Klus-Stańska i Nowicka podają następujące przykłady: „Temat Jesień może polegać na kolorowaniu ilustracji, nauce piosenki o kasztanach lub pogadance na temat zmian w przyrodzie zachodzących jesienią. Nie wniesie to niczego odkrywczego do myślenia i wiedzy uczniów" (Klus-Stańska, Nowicka 2005: 184). Autorki przytaczają również propozycję opracowywania z uczniami tematu „Las” z towarzyszeniem piosenki Jesteśmy jagódki (Klus-Stańska, Nowicka 2005: 189). Budzi to spore wątpliwości natury dydaktycznej. Również Rafał Majzner zauważa, że piosenka dziecięca w zintegrowanym modelu nauczania stanowi jedynie tło dla innych zajęć, z jego badań zaś wynika jednoznacznie, że tekst utworu prawie zawsze jest powiązany z tematem bloku dnia (Majzner 2017: 203-207).

Piosenka dziecięca na stałe wpisała się w nauczycielski skrypt lekcji w nauczaniu początkowym, o czym świadczą również prowadzone przeze mnie zajęcia ze studentami wczesnej edukacji. Przygotowując scenariusze zajęć dla klas I-III, większość spośród siedemdziesięciorga studentów zaproponowała „realizację” wybranego 
przez siebie tematu poprzez wprowadzenie wiersza (rymowanki) i piosenki. Warto zaznaczyć, że wybór piosenki do śpiewania był losowy - zwykle był to pierwszy tytuł, który pojawiał się po wpisaniu w wyszukiwarkę internetową hasła "piosenka o... (wiośnie, jesieni, rodzinie, zwierzętach itp.)". Studenci przyznali, że nie zapoznawali się bliżej z wybranym przez siebie utworem, ponieważ uważali, że skoro sam tytuł piosenki „odpowiada” tematowi zajęć, to nie ma potrzeby podejmowania krytycznego namysłu nad jej treścią. Podejrzewam, że jest to efekt socjalizacji szkolnej, której sami doświadczyli jako uczniowie. Wątek ten wymagałby jednak przeprowadzenia bardziej wnikliwych badań, toteż został on w tym miejscu jedynie zasygnalizowany.

\section{Podsumowanie}

Nie ulega wątpliwości, że wśród dostępnych piosenek dziecięcych znaleźć można utwory wartościowe pod względem artystycznym, a także takie, które stymulują rozwój poznawczy poprzez na przykład ułatwienie zapamiętania wybranych informacji, wzbogacanie słownictwa dziecka, stawianie pytań o różne sfery życia człowieka. Nie zgodzę się jednak ze stwierdzeniem, że poprzez naukę piosenki o wiośnie, której celem jest ukazanie artystycznej (niekiedy pseudo-artystycznej) wizji tej pory roku, dziecko zdobędzie wiedzę o porach roku jako o zjawisku przyrodniczym. Takie wykorzystywanie piosenek na lekcjach we wczesnej edukacji budzi raczej moje skojarzenia z nauczycielskimi strategiami przetrwania Petera Woodsa: piosenka dziecięca plasuje się w tym ujęciu gdzieś pomiędzy „Rytuałem i rutyną", tworzącymi „znane wszystkim ramy zapewniające poczucie bezpieczeństwa” a „Terapią zajęciową”, której celem jest „robić coś, ciągle robić, bez względu na to, czy to ma sens" (Janowski 1995: 184).

Warto byłoby zatem raz jeszcze przemyśleć, jakie miejsce piosenka dziecięca może i powinna zajmować we wczesnej edukacji. Proponuję, aby w pierwszej kolejności skoncentrować się na wyborze wysokiej jakości utworów dla dzieci, niekoniecznie związanych tematycznie $\mathrm{z}$ treściami omawianymi w ramach innych obszarów edukacyjnych. Zamiast szukania powierzchownych związków danej piosenki z tematem wiodącym można podjąć głębszą refleksję nad jej przekazem, przeprowadzić analizę warstwy słownej i melodycznej, a wreszcie zaprosić uczniów do zaprezentowania własnych interpretacji (słownych, muzycznych, wokalnych, plastycznych). Wówczas piosenka dziecięca znów będzie mogła pełnić funkcję edukacyjną. 


\section{Literatura}

Cackowska M., 2015, Wzrastać radośnie w przedszkolnym i szkolnym kiczu. Pytania o współczesna alfabetyzacje wizualna dzieci [w:] (Anty)edukacja wczesnoszkolna, red. D. Klus-Stańska, Kraków: Oficyna Wydawnicza Impuls.

Danielewicz W.J., 2013, Nie ma dzieci niezdolnych muzycznie, Lublin: Towarzystwo Naukowe Katolickiego Uniwersytetu Lubelskiego.

Dyląg J., 2006, Jak przeciwdziałać stereotypom w edukacji muzycznej? M. Suświłło, Olsztyn: Wydawnictwo Uniwersytetu Warmińsko-Mazurskiego.

Frołowicz E., 2011, Konsonanse i dysonanse wczesnoszkolnej edukacji muzycznej, Gdańsk: Akademia Muzyczna im. Stanisława Moniuszki.

Janowski A., 1995, Uczeń w teatrze życia szkolnego, Warszawa: Wydawnictwa Szkolne i Pedagogiczne.

Kamińska B., 2013, Edukacja muzyczna w koncepcji polskiej myśli pedagogicznej (przeszłość, teraźniejszość, współczesność) [w:] Tradycje myśli pedagogicznej w nauczaniu muzyki, red. A. Michalski, Gdańsk: Wydawnictwo Athenae Gedanenses.

Klus-Stańska D., Nowicka M., 2005, Sensy i bezsensy edukacji wczesnoszkolnej, Warszawa: Wydawnictwa Szkolne i Pedagogiczne.

Majzner R., 2017, Wybrane kierunki optymalizacji edukacji muzycznej w klasach początkowych szkoły podstawowej w opiniach studentów, „Zeszyty Naukowe Wyższej Szkoły Humanitas. Pedagogika" nr 14.

Opie I., Opie P., 1959, The Lore and Language of Schoolchildren, Oxford: Oxford University Press.

Przychodzińska-Kaciczak M., 1979, Polskie koncepcje powszechnego wychowania muzycznego. Tradycje - współczesność, Warszawa: Wydawnictwa Szkolne i Pedagogiczne.

Sławiński J., 1988, Słownik terminów literackich, Wrocław: Zakład Narodowy im. Ossolińskich. Sośnicki K., 1967, Rozwój pedagogiki zachodniej na przełomie XIX i XX wieku, Warszawa: Państwowe Zakłady Wydawnictw Szkolnych.

Suchodolski B., 1965, Współczesne problemy wychowania estetycznego [w:] Wychowanie przez sztukę, red. I. Wojnar, Warszawa: Państwowe Zakłady Wydawnictw Szkolnych.

Szatan E., 2006, Ekspresja muzyczno-ruchowa jako zaniedbany obszar edukacji muzycznej dziecka [w:] Zaniedbane i zaniechane obszary edukacji w szkole, red. M. Suświłło, Olsztyn: Wydawnictwo Uniwersytetu Warmińsko-Mazurskiego.

Szatan E. (red.), 2007, Wybrane problemy wczesnej edukacji artystycznej, Gdańsk: Fundacja Rozwoju Uniwersytetu Gdańskiego.

Uchyła-Zroski J., 2013, Założenia estetyczne wychowania muzycznego w świetle polityki oświatowo-kulturalnej lat 70. XX wieku [w:] Tradycje myśli pedagogicznej w nauczaniu muzyki, red. A. Michalski, Gdańsk: Wydawnictwo Athenae Gedanenses.

Walencik-Topiłko A., 2016, Logorytmika - zarys historii, podstawy teoretyczne, zastosowanie praktyczne [w:] Emil Jaques-Dalcroze i jego idee w edukacji, sztuce i terapii, red. E. Szatan, E. Muzioł, A. Komorowska-Zielony, Gdańsk: Wydawnictwo Uniwersytetu Gdańskiego.

Wojnar I. (red), 1965, Wychowanie przez sztukę, Warszawa: Państwowe Zakłady Wydawnictw Szkolnych. 


\section{Streszczenie}

Celem artykułu jest problematyzacja pedagogicznej kategorii piosenki dziecięcej oraz krytyczna charakterystyka funkcji, które spełnia ona we wczesnej edukacji. Zostały tu przywołane różne sposoby ujmowania piosenki dziecięcej jako specyficznego tekstu kultury, a także zarysowano pokrótce jej miejsce w zorganizowanych formach wczesnej edukacji muzycznej. Z literatury przedmiotu oraz z praktyki własnej autorki wynika, że postulowana wartość (edukacyjna, artystyczna, wychowawcza) piosenki dziecięcej zanika $\mathrm{w}$ obliczu chaosu pojęciowego i organizacyjnego związanego z wymogiem prowadzenia tzw. edukacji zintegrowanej.

\section{Słowa kluczowe}

piosenka dziecięca, muzyka dziecięca, wczesna edukacja, oferta kulturalna dla dzieci

\section{Summary}

Jarring notes in children's songs.

The obvious and not obvious functions of the children's songs

in early education

The aim of this article is to problematize the category of children's song and to critically characterise the functions that children's songs fulfil (or should fulfil) in early education. The author presents various perspectives of describing children's songs as specific texts of culture, as well as points out their place in organized forms of early music education. Both subject literature and the author's personal experience reveal that the postulated value of children's songs vanishes when confronted with the requirement of so called "integrated education".

\section{Keywords}

children's song, music for children early education, cultural offer for children 